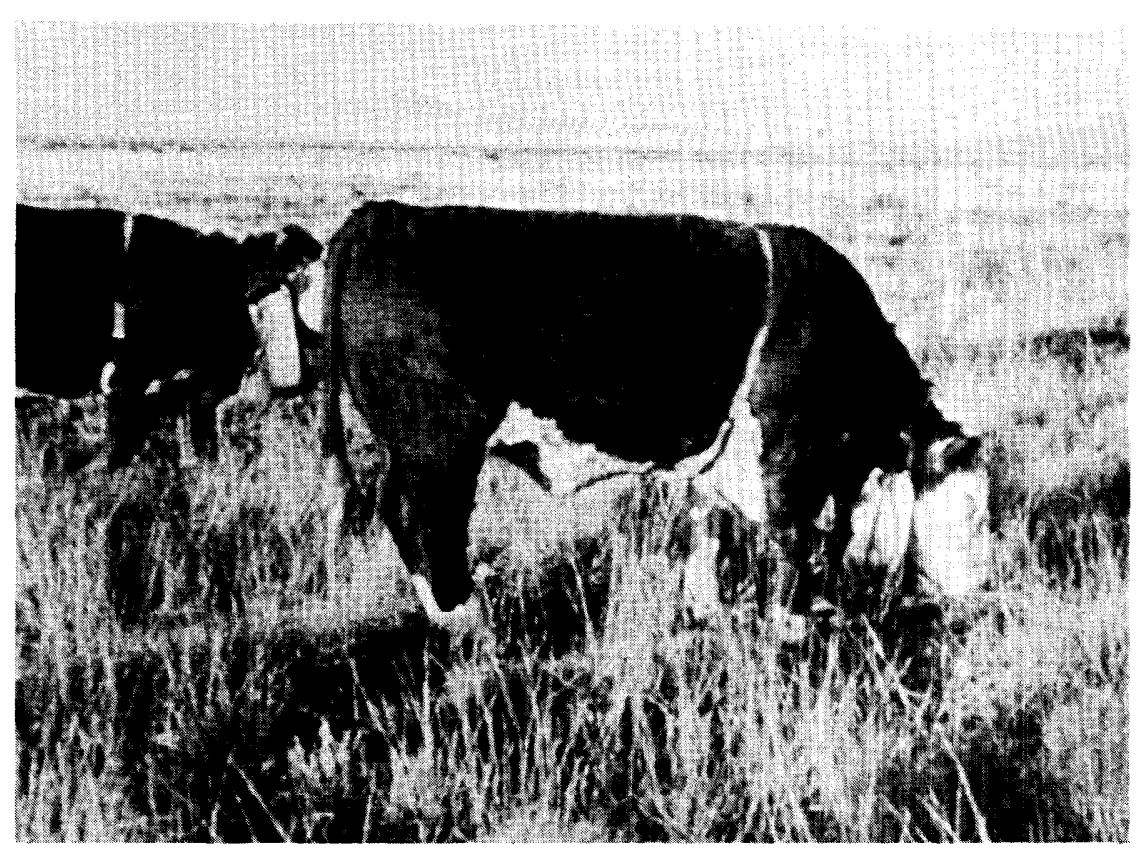

Esophageal fistulated steers fitted with forage collection bags grazing mixed semidesert grassland.

\title{
Cattle Diets on Semidesert Grassland: Nutritive Content
}

\section{R. E. ROSIERE, J. D. WALLACE, AND R. F. BECK}

Highlight: $A$ study of chemical composition and organic matter digestibility of cattle diets was conducted on semidesert grassland in southern New Mexico during different seasons. Forage quality was highest in the spring. Fall diets were lower in digestibility, contained less crude protein and the least estimated digestible energy. Level of protein in fall diets was greater than requirements for dry cows but was less than recommended levels for lactating cows or growing calves. $A$ stepwise regression equation showed that protein accounted for more variation in in vitro digestibility than did other components.

More than a million cattle graze semidesert grassland throughout the Southwest. Ranch enterprises are vital to the economy of this region, but cattlemen are finding it increasingly difficult to obtain a profit from range operations. Ranchers can remain in business only by increasing production and efficiency. Beef production can be increased by nutritive evaluation of cattle diets but such information is limited. This investigation was conducted to study the nutritive value of diets selected by cattle on semidesert rangeland.

Authors are graduate research assistant, range nutritionist, and range ecologist, respectively, Department of Animal, Range and Wildlife Sciences, New Mexico State University, Las Cruces.

This report is Journal Article 519 from the Agricultural Experiment Station, New Mexico State University.

Manuscript received May 31, 1974.

\section{Experimental Procedure}

Four esophageal fistulated Hereford steers were used to sample diets from a southern New Mexico semidesert range. Diets were sampled during 10-day periods at five different seasons. Steers grazed study pastures 14 to 21 days prior to collection periods for all but October collections. During each period forage was collected from a continuously grazed

Table 1. Average chemical composition, in vitro organic matter digestibility, and estimated digestible energy in cattle diets. ${ }^{1}$

\begin{tabular}{|c|c|c|c|c|c|}
\hline \multirow[b]{3}{*}{ Item } & \multicolumn{5}{|c|}{ Year and season } \\
\hline & \multicolumn{2}{|c|}{1972} & \multicolumn{3}{|c|}{1973} \\
\hline & Summer & Fall & Winter & Spring & Summer \\
\hline $\begin{array}{l}\text { Organic matter } \\
(\mathrm{OM})(\%)\end{array}$ & $80.8^{b^{2}}$ & $86.8^{\mathrm{a}}$ & $80.5^{\mathrm{b}}$ & $86.0^{\mathrm{ab}}$ & $87.6^{\mathrm{a}}$ \\
\hline $\begin{array}{l}\text { Composition of } \\
\text { OM: }\end{array}$ & & & & & \\
\hline $\begin{array}{l}\text { Protein }(\%) \\
\text { Fiber }(\%) \\
\text { Lignin }(\%)\end{array}$ & $\begin{array}{l}12.7^{\mathrm{a}} \\
52.9^{\mathrm{b}} \\
12.0^{\mathrm{ab}}\end{array}$ & $\begin{array}{l}7.3^{\mathrm{b}} \\
63.3^{\mathrm{a}} \\
12.5^{\mathrm{ab}}\end{array}$ & $\begin{array}{l}13.0^{\mathrm{a}} \\
53.8^{\mathrm{b}} \\
13.9^{\mathrm{a}}\end{array}$ & $\begin{array}{r}13.7^{\mathrm{a}} \\
46.8^{\mathrm{c}} \\
7.9^{\mathrm{c}}\end{array}$ & $\begin{array}{l}11.5^{\mathrm{a}} \\
52.4^{\mathrm{bc}} \\
10.5^{\mathrm{b}}\end{array}$ \\
\hline $\begin{array}{l}\text { In vitro OM } \\
\text { digestibility }(\%)\end{array}$ & $59.5^{\mathrm{a}}$ & $39.2^{\mathrm{c}}$ & $48.1^{b}$ & $63.7^{\mathrm{a}}$ & $48.9^{b}$ \\
\hline $\begin{array}{l}\text { Estimated di- } \\
\text { gestible energy } \\
\text { (Mcal } / \mathrm{kg})\end{array}$ & $2.2^{\mathrm{a}}$ & $1.4^{\mathrm{c}}$ & $1.8^{b}$ & $2.4^{\mathrm{a}}$ & $1.8^{\mathrm{b}}$ \\
\hline
\end{tabular}

${ }^{1}$ Each value represents the mean of all steers over both grazing systems. ${ }^{2}$ Means on the same line with different superscripts are significantly different $(P<.05)$.

${ }^{3}$ Predicted according to Rittenhouse et al. (1971). 
Table 2. Average seasonal composition (\%) of grasses, forbs, and shrubs in steer diets on semidesert ranges. ${ }^{1}$

\begin{tabular}{lrrrrrr}
\hline & \multicolumn{5}{c}{ Year and season } \\
\cline { 2 - 4 } Forage class & \multicolumn{2}{c}{1972} & & \multicolumn{3}{c}{1973} \\
\cline { 2 - 4 } \cline { 5 - 7 } & Summer & Fall & & Winter & Spring & Summer \\
\hline Grasses & 70 & 55 & & 32 & 15 & 42 \\
Forbs & 21 & 33 & & 57 & 11 & 36 \\
Shrubs & 2 & 6 & 4 & 69 & 15 \\
Unidentified & 7 & 6 & & 7 & 5 & 7 \\
\hline
\end{tabular}

${ }^{1}$ Values represent averages over both grazing systems.

pasture and from one of three pastures within a seasonal suitability grazing system. The two pastures were sampled on alternate days and forage collections were made once daily at daybreak after steers had been penned ovcrnight. Steers were hazed to preselected areas and allowed to graze freely until about $1 \mathrm{~kg}$ of grazed forage was acquired. Collected forage was spread evenly over plastic trays and dried for 24 hours at $55^{\circ} \mathrm{C}$ in a forced-air oven. After drying it was ground through a $1-\mathrm{mm}$ screen in a Wiley mill.

Dry matter, ash, and Kjeldahl nitrogen were determined according to Ass. Offic. Agr. Chem. (1965) procedures. Fiber and lignin were analyzed by acid detergent techniques (Van Soest, 1963) while organic matter digestibility was estimated by the method of Tilley and Terry (1963). Digestible energy values were predicted from organic matter digestibility using a regression equation developed by Rittenhouse et al. (1971). Details of experimental pastures and climate were reported by Rosiere (1973) and Rosiere et al. (1975). Statistical methods used were those described by Steel and Torrie (1960).

\section{Results and Discussion}

There were seasonal differences $(\mathrm{P}<0.01)$ in nutrient components and in vitro organic matter digestibility (Table 1). Grazing systems had no significant effect on these factors nor were there significant differences among diets of individual steers (Rosiere, 1973), thus, data presented in Table 1 are averages of all steers and both grazing systems. Digestibility of summer diets was lower in 1973 than in 1972 even though there were differences only in forb portions of these diets (Table 2).

Fall diets were lower in protein and organic matter digestibility than were those during other seasons (Table 1). Nutrient content of fall herbage was not evaluated, but it was noted that there was less green plant material at this season than during any other. Lowest protein level coupled with lowest digestibility indicated that fall was the most critical nutritive period and that the most benefit from supplementation would have been expected during this period.

It was impossible to determine accurately whether protein in fall diets was adequate to meet cattle requirements because forage intake was unknown. Review of beef cattle requirements (National Res. Counc., 1970) showed that the crude protein level in fall diets (7.3\%) exceeds the $5.9 \%$ recommended for dry, pregnant cows but it is lower than the $9.2 \%$ and $11.1 \%$ suggested for lactating cows and $200-\mathrm{kg}$ heifers gaining $0.5 \mathrm{~kg}$ per day, respectively. Protein supplementation might have been beneficial for lactating cows and young, growing cattle but not for dry cows. Dry cows grazing the study pastures were unsupplemented and produced an $88 \%$ calf crop in spring of 1973 . During fall seasons, most cattle herds on semidesert ranges contain a mixture of lactating and dry cows as well as replacement heifers. In some
Table 3. Composition of available herbage and cattle diets during spring and summer of 1973.

\begin{tabular}{|c|c|c|c|c|}
\hline \multirow[b]{3}{*}{ Item } & \multicolumn{4}{|c|}{ Season } \\
\hline & \multicolumn{2}{|c|}{ Spring } & \multicolumn{2}{|c|}{ Summer } \\
\hline & Herbage & Diet & Herbage & Diet \\
\hline $\begin{array}{l}\text { Organic matter } \\
(\mathrm{OM})(\%)\end{array}$ & 86.4 & 86.0 & 89.2 & 87.6 \\
\hline $\begin{array}{c}\text { Composition of OM: } \\
\text { Protein (\%) } \\
\text { Fiber (\%) } \\
\text { Lignin (\%) }\end{array}$ & $\begin{array}{r}9.5 \\
48.2 \\
9.7\end{array}$ & $\begin{array}{r}13.7 \\
46.8 \\
7.9\end{array}$ & $\begin{array}{l}10.0 \\
46.8 \\
10.0\end{array}$ & $\begin{array}{l}11.5 \\
52.4 \\
10.5\end{array}$ \\
\hline $\begin{array}{l}\text { In vitro OM } \\
\text { digestibility }(\%)\end{array}$ & 49.3 & 63.7 & 44.6 & 48.9 \\
\hline $\begin{array}{l}\text { Estimated digestible } \\
\text { energy }^{1}(\mathrm{Mcal} / \mathrm{kg})\end{array}$ & 1.8 & 2.4 & 1.6 & 1.8 \\
\hline
\end{tabular}

${ }^{1}$ Predicted according to Rittenhouse et al. (1971).

cases, weaned calves are wintered on these same pastures. Consequently, supplementation programs would vary with individual ranches.

There were no significant differences in protein levels of diets among seasons other than fall (Table 1). Increase in protein content from fall to winter was due to growth of highly palatable forbs. Herbel and Nelson (1966) found that cattle grazed various forbs and shrubs during winter and felt that this maintained adequate protein and carotene in diets. Winter protein supplementation of dry, pregnant cows is probably unnecessary on ranges where forbs are plentiful. Winter forb growth is dependent upon adequate precipitation and, consequently, does not always occur. Under such conditions winter and spring may be more critical than fall. Frequent drought may make supplementation or even "dry-lotting" necessary in summer. Cattle diets on desert grassland are dynamic and no fixed seasonal trend can be established to fit all years.

Moir (1961) reported a high correlation $(r=0.98)$ between digestible energy and dry matter digestibility of numerous roughages fed to ruminants. Rittenhouse et al. (1971) developed a regression equation to predict digestible energy (DE) from organic matter (OM) digestibility of forage grazed by cattle on Great Plains grasslands:

$$
\mathrm{DE}, \mathrm{Mcal} / \mathrm{kg} \mathrm{OM}=0.039 \text { (\%OM digestibility) }-0.10 \text {. }
$$

This equation is similar to that derived by Moir (1961), and its application to desert grassland diets should indicate seasonal trends in DE. Estimated DE values were highest in the spring and lowest in the fall (Table 1). These values may be compared to the requirements (National Res. Counc., 1970) by converting metabolizable energy (ME) values to $\mathrm{DE}$ using the

Table 4. Numbers of steers required for sampling nutritive components and in vitro organic matter digestibility within $10 \%$ of the mean with 95\% confidence during each collection period. ${ }^{1}$

\begin{tabular}{|c|c|c|c|c|c|}
\hline \multirow[b]{3}{*}{ Item } & \multicolumn{5}{|c|}{ Year and season } \\
\hline & \multicolumn{2}{|c|}{1972} & \multicolumn{3}{|c|}{1973} \\
\hline & Summer & Fall & Winter & Spring & Summer \\
\hline
\end{tabular}

In vitro OM
digestibility

Protein

Fiber

Lignin

2

5

5

24

26

84

3

25

8
5
10
28

2

7

${ }^{1}$ Each value represents an average of the number of steers required under both grazing systems. 


\section{NRC conversion:}

\section{$\mathrm{DE}$ in $\mathrm{Mcal} / \mathrm{kg}=\mathrm{ME}$ in $\mathrm{Mcal} / \mathrm{kg} \times 1.22$}

This gives a DE level for lactating cows of $2.5 \mathrm{Mcal} / \mathrm{kg}$ and that for dry, pregnant cows of $2.2 \mathrm{Mcal} / \mathrm{kg}$. Estimated DE level in the 1972 summer diet $(2.2 \mathrm{Mcal} / \mathrm{kg})$ was adequate for dry cows but not for those lactating, while spring, 1973, diets (2.4 $\mathrm{Mcal} / \mathrm{kg}$ ) approached adequacy for lactating cows. Winter and summer diets for $1973 \mathrm{had}$ estimated DE values $(1.8 \mathrm{Mcal} / \mathrm{kg}$ for both) which were below recommended levels for dry cows. These data point out that DE levels of cattle diets on semidesert ranges may often be marginal or below required levels for desired production.

Nutrient content of available herbage during spring and summer of 1973 was compared to diets during these seasons (Table 3). Herbage samples had the same species composition as range standing crop (Rosiere et al., 1975). Steers selected forage that was $14.4 \%$ and $4.3 \%$ more digestible than spring and summer herbage, respectively. Compared to available herbage, spring diets contained $4.2 \%$ more protein, $1.4 \%$ less fiber and $1.8 \%$ less lignin. Summer diets contained $1.5 \%$ more protein but $5.6 \%$ more fiber and $0.5 \%$ more lignin than available herbage. Steers were not able to select as nutritious a diet in relation to herbage in summer as in spring. This was attributed to drought, reduced vegetational variety, and advanced maturity.

A regression equation $\left(r^{2}=0.86\right)$ was developed for predicting in vitro organic matter digestibility from various chemical constituents:

$$
\mathrm{Y}=52.30+2.15 \mathrm{x}_{1}-1.16 \mathrm{x}_{2}+1.00 \mathrm{x}_{3}-0.52 \mathrm{x}_{4}
$$

where $\mathbf{x}_{1}=$ protein, $\mathbf{x}_{2}{ }^{\cdot}=$ lignin, $\mathbf{x}_{3}=$ ash and $\mathbf{x}_{4}=$ fiber.

Protein was more closely correlated in vitro digestibility $(r=$ 0.75) than were other components. Brown et al. (1968) reported a correlation of $r=0.92$ betwecn protcin and digestible dry matter in grass hays. Consumption of large quantities of browse and weathered grass was possibly responsible for our weaker association between protein content and organic matter digestibility compared to that obtained by Brown et al. (1968). Rao et al. (1973) studied cattle diets on tallgrass prairie and developed similar regression equations for predicting in vitro digestibility. They found that digestibility was most closely correlated to crude protein and fiber. The correlation between lignin content and digestibility of steer diets in the present study was $r=-0.59$. Lignin determinations were considerably more tedious and time-consuming than nitrogen analyses, thus as a single indicator for nutritive value of steer diets, protein was preferred over lignin.

The number of steers required to estimate nutrient composition and digestibility of forage within $10 \%$ of the mean with $95 \%$ confidence varied from one to 84 (Table 4). A maximum of 10 steers would have been sufficient to sample organic matter digestibility, protein, and fiber if the fall season was disregarded. Greatest steer requirements were in the fall, when an individual steer selected a diet considerably higher in protein than those selected by other steers (Rosiere, 1973). Requirements for sampling fall diets might have been less if a longer grazing period had preceded fall collections. Larger numbers of steers were required to estimate lignin than other components. Wallace et al. (1972) found that lignin content of forage was not significantly affected by salivary contamination. Thus, it seemed likely that variation in lignin occurred naturally within forage or resulted from laboratory techniques. Obioha et al. (1970) found that more animals and/or sampling days were required to measure forage lignin content with the same degree of precision as nitrogen. Wallace and Van Dyne (1970) reported that more cattle were required to adequately sample fecal lignin than fecal nitrogen. From results shown in Table 4, it was concluded that six to eight steers should be used when sampling nutritive value of cattle diets on semidesert rangeland. Similar numbers of cattle were necessary to sample diets on tallgrass and midgrass pastures (Obioha et al., 1970) and sandhill range (Wallace and Van Dyne, 1970).

\section{Conclusions}

Nutrient content of forage selected by cattle from desert grassland varies widely among different seasons and probably among the same season in different years. As such, definite supplementation schedules would be difficult to establish and restricted in application. The value of generalized recommendations for supplemental feeding on semidesert rangeland is also limited by variation in kinds and classes of cattle forming individual herds. Protein content of fall and winter diets may be inadequate for maintenance of lactating cows grazing depleted pastures with limited growth of forbs. There are indications that energy concentrations of diets may be more critical than protein, especially during winter or summer drought. Protein is superior to lignin as an indicator of nutritive value when evaluating forage from this type of rangeland.

\section{Literature Cited}

Association of Official Agricultural Chemists. 1965. Official Methods of Analysis (10th Ed.). Washington, D.C. 957 p.

Brown, R. H., R. E. Blaser, and J. P. Fontenot. 1968. Effect of spring harvest date on nutritive value of orchardgrass and timnthy. I. Anim. Sci. 27:562-567.

Herbel, C. H., and A. B. Nelson. 1966. Species preferences of Hereford and Santa Gertrudis cattle on a southern New Mexico range. J. Range Manage. 19:177-181.

Moir, R. J. 1961. A note on the relationship between the digestible dry matter and the digestible energy content of ruminant diets. Australian J. Exp. Agr. and Anim. Husb. 1:24-26.

National Research Council. 1970. Nutrient requirements of beef cattle (4th Ed.). National Academy of Sciences, Washington, D.C. 55 p.

Obioha, F. C., D. C. Clanton, L. R. Rittenhouse, and C. L. Streeter. 1970. Sources of variation in chemical composition of forage ingested by esophageal fistulated cattle. J. Rangc Managc. 23:133-136.

Rao, M. R., L. H. Harbers, and E. F. Smith. 1973. Seasonal changes in nutritive value of bluestem pastures. J. Range Manage. 26:419-422.

Rittenhouse, L. R., C. L. Streeter, and D. C. Clanton. 1971. Estimating digestible energy from dry and organic matter in diets of grazing cattle. J. Range Manage. 24:73-75.

Rosiere, R. E. 1973. Cattle diets on semidesert grassland. MS Thesis. New Mexico State Univ., Las Cruces. 139 p.

Rosiere, R. E., R. F. Beck, and J. D. Wallace. 1975. Cattle diets on semidesert grassland: Botanical composition. J. Range Manage. 28:89-93.

Steel, R. G. D., and J. H. Torrie. 1960. Principles and procedures of statistics. McGraw-Hill Book Co., Inc., New York. 481 p.

Tilley, J. M. A., and R. A. Terry. 1963. A two-stage technique for the in vitro digestion of forage crops. J. British Grassland Soc. 18:104-111.

Van Soest, P. J. 1963. Use of detergents in the analysis of fiberous feeds. II. A rapid method for the determination of fiber and lignin. J. Ass. Offic. Agr. Chem. 46:829-835.

Wallace, J. D., D. N. Hyder, and G. M. Van Dyne. 1972. Salivary contamination of forage selected by esophageal fistulated steers grazing sandhill grassland. J. Range Manage. 25:184-187.

Wallace, J. D., and G. M. Van Dyne. 1970. Precision of indirect methods for estimating digestibility of forage consumed by grazing cattle. J. Range Manage. 23:424-430. 